Shumeiko Natalia, Senior Lecturer, PhD (Pedagogical Sciences), Kyiv National University of Trade and Economics, 19, Kyoto str., Kyiv, 02156, Ukraine

ORCID: 0000-0002-7859-7519

Researcher ID: A-8042-2019

\title{
SOCIAL MEDIA: IMPACT ON LANGUAGE TRAINING
}

In the globalized world, when people who have grown up with personal computers are often called digital generation, understating of foreign languages is a prerequisite for successful employment in the labor market and effective business collaboration. The use of various social networking tools has influenced students' everyday life, and language learning is no exception. Popular social media, such as Facebook, Pinterest and YouTube, offer educators the ways to reinvigorate the classroom climate in higher education institution. Without any doubt, social media provide opportunities for students to develop digital skills, multiliteracy practices, to interact in and through the target language, to improve their pragmatic and linguistic proficiency.

Keywords: social media, language training, higher education.

\section{Шумейко Наталія. Соціальні ЗМІ: вплив на мовне навчання.}

У глобалізованому світі, коли людей, які виросли за допомогою персональних комп'ютерів, часто називають ицфровим поколінням, знання іноземних мов є необхідною умовою успішного працевлаштування на ринку пращі та ефективного ділового співробітництва. Використання різних інструментів сочіальних мереж вплинуло на повсякденне життя учнів, $і$ вивчення мови не $\epsilon$ винятком. Популярні соиіальні медіа, такі як Facebook, Pinterest та YouTube, пропонують викладачам способи активізувати клімат групи у вищому навчальному закладі. Без будь-якого сумніву, соиіальні медіа надають студентам можлливість розвивати циифрові навички, практики багатомовної грамотності, взаємодіяти на иільовій мові та через неї, вдосконалювати свою прагматичну та лінгвістичну майстерність.

Ключові слова: соціальні медіа, мовна підготовка, вища освіта.

Relevance of research topic. Learning tools, intended to improve students' language skills in the process of language training, may refer to computer-based educational resources. Accordingly, social media provide immediate motivation for 
representatives of digital era and encourage learners to improve current level of proficiency in foreign language.

Formulation of the problem. Nowadays, the issue of bringing social media resources into foreign language learning process is relevant, as social media offer new prospects for students, involving learners in online learning trajectory, expanding the boundaries of the process of learning, improving indispensable language skills.

Analysis of recent researches and publications. Higher education space is definitely linked to the wide-ranging effects of globalization. In particular, the explosive growth of using social media in contemporary society has spurred a great increase of scientists' interest to language learning and training, involving appropriate Internet-based resources. Furthermore, the large-scale study, presented in Bologna Process Implementation Report in 2018, indicates: «digital technologies potentially may broaden access to higher education and to lifelong learning. They give learners the opportunity to participate in education in a more flexible way - both in time and in space» (The European Higher Education Area, 2018, 74). The scholars (G. Dettori, M. Hafedh, L. Lomicka, G. Lord, V. Li, H. Slim, S. Torsani, etc.) in modern scientific papers elucidated a wide array of the themes related to social networking and language learning. Researchers clarified the problems concerning the academic usage of social media, the use of social media for collaborative learning, the role of social media in teaching-learning process (M. Ali, W. Al-rahami, M. Othman, M. Musa, K. Devi, E. Gouthami, V. Lakshmi, etc.). Moreover, contemporary pedagogical explorations are linked to social media use in higher education (I. Anagnostopoulos, E.-A. Paraskevopoulou-Kollia, G. Zachos, etc.).

Social media as a tool for communication is an effective means of interaction (Ali, 2017, 553-561; Al-rahimi, 2013, 90-95). In the modern world, students know the tenet of working in social networking websites, such as Facebook, YouTube, Pinterest, Instagram, Twitter, and others. It is rather relevant to indicate that in order to maintain motivation the higher education lecturer acts as a guide and controls students' activities. At the same time, students regulate their own learning. Furthermore, collaborative learning helps students to decide one shared objective together, as the lecturer is no longer in full control. So, a lecturer and a student may be seen as both a trainee and a trainer. University students find communication with the lecturer inspiring and useful (Devi, 2019, 96-103). Moreover, the combination of formal and informal learning is recommended as the way to enhance official language learning (Li, 2017, 148-153; Dettori\&Torsani, 2013, 93-100).

Setting objectives. The current research is aimed at investigating the social media prevalence in Ukraine and distinguishing the theoretical considerations concerning the impact of social media on student's foreign language proficiency.

Presenting main material. The rapid development of computer technologies, globalization and socioeconomic progress has led to an increase in the quantity of people who prefer Facebook as the most effective social networking site. This 
situation is also typical for Ukraine. This can be evidenced by the 'Stat counter Global Stats data relating to the use of social media in Ukraine in 2018 and 2019 (Stat counter Global Stats, 2019). The author systematized the results of the analysis, based on 'Stat counter Global Stats', and offered consequences in the drawings1 and 2. So, it was exposed that in July 2019 Ukrainian people chose the following social media: 52,35\% of people in Ukraine preferred Facebook; 21,68\% - Pinterest; 8,70\% - YouTube; 5,75\% - Twitter; 3,99\% - Instagram; 7,53\% - other social media. In July 2018 Ukrainian people preferred the following social media: 40,68\% - Facebook; 4,27\% Pinterest, 14,60\% - Twitter, 17,26\% - YouTube, 9,08\% - Instagram, 14,11\% - other social networking sites (Drawing1 and Drawing2).

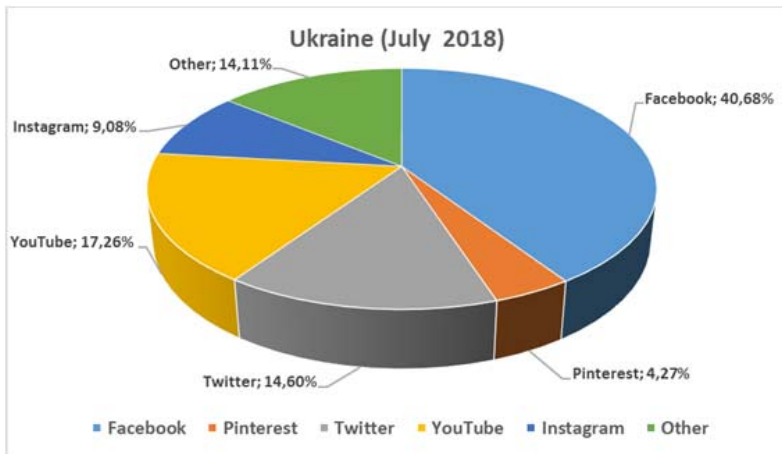

Drawing 1. The use of Social Media in Ukraine in July 2018

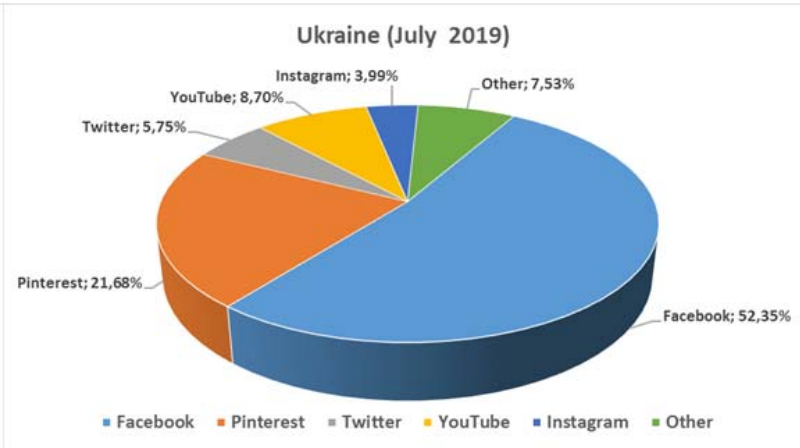

Drawing 2. The use of Social Media in Ukraine in July 2019

As a result of conducted comparative analysis relating to popularity of using social media in Ukraine in July 1018 and July 2019 it was revealed that Ukrainians prefer Facebook rather than other social media, it's worth noting that the number of Facebook users has increased in 2019, YouTube is very popular social networking site in Ukraine. Pinterest's fame in Ukraine is considerable. It is confirmed by increasing number of Ukrainians who chose Pinterest in July 2019 comparing with July 2018. The conducted analysis indicates that social media has already integrated into Ukrainians' daily life. Ukrainians use social networking sites to connect with each other, to share ideas, opinions and other contents, to stay in touch with friends.

Social media sites have become influential communication spaces among university students. Therefore incorporating of social media into language classes at the universities of Ukraine is compelling, as a great number of students in Ukraine use social media at least once per day. We address key considerations to adding Facebook, YouTube and Pinterest tools in the language classroom. Therefore, we focus on the conversation concerning three types of social media platforms: Facebook as prominently widespread social media site (Slim \&Hafedh, 2019, 56-71); YouTube popular social media site that is an outstanding option for watching videos; Pinterest a tool that allows users to share images online. 
According to certain scholars, Facebook can be a valuable tool for improving language skills for instance reading and writing. In reading - learners may gain experience in consequences of reading messages, in writing - through composing messages (Slim \& Hafedh, 2019, 60). Moreover, YouTube is one of the most popular websites in Ukraine. In this regard, it is worth mentioning that YouTube is the vast resource for enriching content in the language classroom. Furthermore, Pinterest is a «visual discovery tool that people use to collect ideas for their different projects and interests». Students can make and share so called «boards» of visual bookmarks («Pins») that are used to do projects, save articles, etc. (Lomicka \& Lord, 2016, 255-268).

Conclusion. Today the higher education institutions are gradually taking social media resources in the foreign language course curriculum. Progressively, social media tools are integrating into Ukrainian higher education institutions. Social networking sites, predominantly Facebook and Pinterest, are becoming increasingly widespread in modern Ukrainian realities by means of vastly growing number of Internet users. Social media have generated a tactic that brings individuals together, influencing both lecturers and learners, encouraging students to study and develop their foreign language skills, having in mind the veracity that social media unlock the path to education worldwide.

\section{REFERENCES}

1. Ali, M., Yaacob, R.A.I.B.R, Endut, M.N.A.B., \& Langove, N.U. (2017). Strengthening the academic usage of social media: an exploratory study. Journal of King Saud University - Computer and Information Sciences, Vol. 29, Issue 4, 553-561. Retrieved from : https://www.sciencedirect.com/science/article/pii/S131915 7816300787.

2. Al-rahimi, W.M., Othman, M.S., \& Musa, M.A. (2013). Using TAM model to measure the use of social media for collaborative learning. International Journal of Engineering Trends and Technology (IJETT), Vol. 5, No. 2, 90-95. Retrieved from : http://ijettjournal.org/volume-5/number-2/IJETT-V5N2P117.pdf.

3. Dettori, G., Torsani, S. (2013). Enriching formal language learning with an informal social component. Educational Technology and Society, Vol. 4, No. 1, 93-103. Retrieved from : https://www.researchgate.net/publication/235887990 Enriching_Formal_Language_Learning_with_an_Informal_Social_Component.

4. Devi, K.S., M., Gouthami, E., \& Lakshmi, V.V. (2019). Role of social media in teaching - learning process. Journal of Emerging Technologies and Innovative Research (JETIR), Vol. 6, Issue 1, 96-103. Retrieved from : https://www.researchgate.net/publication/330497773_Role_of_Social_Media_in_Teac hing-Learning_Process. 
5. Li, V. (2017). Social Media in English Language Teaching and Learning. International Journal of Learning and Teaching, Vol. 3, No. 2, 148-153. Retrieved from : http://www.ijlt.org/uploadfile/2017/0525/20170525052209836.pdf.

6. Lomicka, L. \& Lord, G. (2016). Social networking and language learning. In: F. Farr \& M. Murray (Ed.). The Routledge handbook of language learning and technology. 255-268. New York. Retrieved from : https://pdfs.semanticscholar.org/ c0d3/cda452775f47680c66a1 be06e08643840913.pdf.

7. Slim, H. \& Hafedh, M. (2019). Social media impact on language learning for specific purposes: a study in English for Business Administration. Teaching English with Technology, 19(1), 56-71. Retrieved from : http://www.tewtjournal.org/ issues/volume-2019/volume-19-issue-1/

8. Stat counter Global Stats (2019). Retrieved from http://gs.statcounter.com.

9. The European Higher Education Area in 2018. Bologna Process Implementation Report (325 p.). (2018). Education, Audiovisual and Culture Executive Agency. BE, Brussels. Retrieved from : http://ec.europa.eu/eurydice

10. Zachos G., Paraskevopoulou-Kollia E.-A. \& Anagnostopoulos I. (2018). Social media use in higher education: a review. Education sciences. 8(4), 194. Retrieved from : https://www.mdpi.com/2227-7102/8/4/194 